Jurnal Agribis

Vol. 7, No.1, Tahun 2021

\title{
ANALISA USAHATANI KUBIS DENGAN MENERAPKAN PENGENDALIAN HAMA TERPADU
}

\author{
Ir. Abdul Rochman ${ }^{1}$ \\ 1,Program Studi Agribisnis, Fakultas Pertanian, Universitas Tulungagung \\ 7 \\ E-mail: abdulrochman2024@gmail.com
}

\begin{abstract}
ABSTRAK
Usaha untuk mewujudkan kesejahteraan masyarakat adalah yang selalu diusahakan, baik oleh pemerintah daerah maupun pemerintah pusat, dengan menggunakan berbagai programnya, yang tentu saja harus tetap memperhatikan potensi yang ada di daerah masing-masing.Agar potensi daerah dapat bermanfaat, maka masyarakat melakukan kegiatan ekonmi, dengan melihat peluang yang ada, sarana dan prasarana ekonomi yang dapat menunjang serta mendorong kegiatan ekonomi tersebut. Salah satunya adalah usaha produk olahan tempe, karena tempe adalah salah satu bahan makanan yang sudah merakyat, dan dikonsumsi hampir setiap hari oleh masyarakat Indonesia, dari masyarakat kalangan atas sampai bawah, yang tidak dibatasai oleh status sosial. Hal ini menarik bagi peneliti untuk mengetahui, berapa pendapatan produsen home industri tempe kripik, dan faktor yang mempengaruhinya. Dari faktor umur, tingkat pendidikan dan pengalaman atau lama usaha, manakah yang paling berpengaruh terhadap pendapatan produsen home industri tempe kripik. Dalam penelitian ini menggunakan metode deskriptif kuantitatif, dengan melakukan survei, sedangkan penentuan daerahnya dilakukan secara sengaja, dengan alasan bahwa Kelurahan Tamanan, Kecamatan Trenggalek, Kabupaten Trenggalek merupakan salah satu daerah sentra home industri tempe kripik yang ada di Jawa Timur. Dari hasil analisis dapat diketahui rata-rata pendapatan produsen home industri tempe kripik, dalam satu kali produksi adalah Rp 695.650,sedangkan faktor umur, tingkat pendidikan dan lama usaha atau pengalaman ternyata tidak berpengaruh terhadap pendapatan, baik secara bersama-sama, maupun secara parsial.
\end{abstract}

Kata Kunci: Faktor Produksi,Home Industri Tempe Kripik, Pendapatan 


\begin{abstract}
Efforts to create public welfare are what the regional and central governments always strive to make, by using various programs and utilizing any potential in each region. In order for the regional potential to be useful, the community shall carry out economic activities, by looking at the opportunities, economic facilities and infrastructure that can support and encourage economic activity. One of the examples is the business of processed tempe products, because tempe is one of the most popular foodstuffs, and is consumed almost every day by Indonesians, from the upper class to the lower classes, who are not limited by social status. This is interesting for researchers to find out the income of the home industry producer of tempe chips, and the factors that influence it. From the factors of age, level of education, and experience or length of business, which one has the most influence on the income of the home industry tempe chips producers. In this study using a quantitative descriptive method, by conducting a survey, while the determination of the area was conducted purposively at Tamanan Village, Trenggalek District, Trenggalek Regency as one of the centers for the home industry for tempe chips in East Java. From the results of the analysis, it can be seen that the average income of the home industry tempe chips producers, in one production was IDR 695,650. The factors of age, education level, and length of business or experience did not significantly affect income, either jointly or partially.
\end{abstract}

Keywords: Production Factor, Home Industry, Tempe Chips, Income 


\section{PENDAHULUAN}

Kesejahteraan masyarakat sangat penting untuk terus menerus di usahakan meningkat, agar mampu mencukupi kebutuhan hidup keluarganya.Kesejahteraan masyarakat merupakan suatu keadaan dimana dapat terpenuhinya kebutuhan material, spiritual, dan sosial masyarakat, agar dapat hidup layak, serta mampu mengembangkan diri, sehingga dapat melaksanakan fungsi sosialnya (UndangUndang no.11 Tahun 2009). Dalam upaya untuk meningkatkan kesejahteraannya atau usaha meningkatkan pendapatannya, seorang pengusaha harus mempunyai keahlian dan ketrampilan untuk mengelola atau mengoptimalkan faktor produksi atau sumberdaya yang ada, agar tujuan usahanya dapat tercapai secara efektif dan efisien.

Tempe merupakan salah satu makanan yang digemari dan sering di konsumsi masyarakat Indonesia sejak jaman dahulu, tetapi sekarang telah mendunia.Tempe adalah bahan makanan yang murah, tetapi kaya gizi, karena banyak kandungan nutrisi, vitamin dan mineral protein yang tinggi. Sebenarnya tempe merupakan salah satu produk olahan yang berbasis bioteknologi (hasil dari fermentasi terhadap biji kedelai dengan menggunakan beberapa jenis kacang Rhizopus, di mana sediaan fermentasi dikenal dengan "ragi tempe"). Tempe kaya akan serat pangan, kalsium, vitamin B (penting untuk memelihara kesehatan saraf), dan zat besi, dengan berbagai kandungan yang mempunyai nilai obat, antara lain antibiotika untuk menyembuhkan infeksi dan antioksidan pencegah penyakit degenarif (Silvia, 2009). Pada akhirnya tempe menjadikannya sebagai makanan sehat, yang murah, namun mempunyai khasiat yang berkilau.

Dalam usaha untuk memperbaiki pendapatannya, produsen tempe melihat peluang untuk memperbaiki bisnisnya, dengan usaha produksi olahan tempe, yaitu tempe kripik. Bentuk bisnis atau usaha yang cocok dalam hal ini adalah industri rumahan atau home industri, Home industri disebut sebagai kegiatan keluarga, yaitu sebagai unit-unit konsumtif dan produktif, yang terdiri dari paling sedikit dua anggota rumah tangga yang sama, sama-sama menanggung pekerjaan makanan dan tempat berlindung (Kimbal, 2015). Home industri dapat pula diartikan sebagai rumah usaha produk barang atau juga perusahaan kecil, karena kegiatan ekonominya di pusatkan di rumah, walaupun skalanya tidak terlalu besar tapi secara tidak langsung dapat membuka lapangan pekerjaan, baik untuk sanak saudara ataupun tetangga di kampung halamannya. Dengan begitu usaha perusahaan kecil ini dapat membantu atau mendukung program pemerintah dalam upaya mengurangi angka pengangguran. 
Bahwa industri rumah tangga(home industri) telah diakui memberikan sumbangan yang cukup besar terhadap pemanfaatan sumber daya manusia, yaitu memberikan peluang kerjadalam upaya mengurangi pengangguran.Disamping itu juga ikut berperan dalam perubahan pola pertanian menuju agroindustri, juga memberikan kesempatan bagi masyarakat untuk mencari alternatif penghasilan tambahan melalui industri rumah tangga (Al-kautsar, 2013). Serta usaha home industri mempuyai peranan yang penting di antaranya : dapat meningkatkan penyerapan tenaga kerja., dapat meningkatkan pendapatan produsen., dapat, meningkatkan ketrampilan produsen, dapat meningkatkan nilai tambah dan kualitas hasil, dan sebagainya. Dan usaha di rumahan atau home industri ini terus berkembang sesuai dengan potensi daerah dan perkembangan dunia wisata, yang saling berkaitan, serta cocok dengan kehidupan masyarakat, Indonesia.

Hal inilah yang menarik bagi peneliti untuk melakukan suatu penelitian atau kajian tentang perkembangan usaha home industri yang berkaitan atau berhubungan dengan bekal keahlian, ketreampilan, pendidikan, pengalaman dan lain sebagainya dari pengusaha atau produsen sebagai pengelola usaha home industri Selain itu juga masih terbatasnya yang melakukan penelitian atau kajian tentang pengaruh factor umur, tingkat pendidikan dan pengalaman atau lama usaha terhadap pendapatan usaha home industri tempe kripik pada kelompok usaha jajanan khas Kabupaten Trenggalek. Adapun tujuan dari pada penelitian ini adalah (1) untuk mengetahui pendapatan produsen home industri tempe kripik, (2) untuk mengetahui factor-faktor yang mempengaruhi pendapatan tersebut, dan (3) untuk mengetahui factor yang paling mempengaruhi pendapatan produsen home industri tempe kripik pada kelompok jajanan khas diLingkungan Kranding, Kelurahan Tamanan, Kecamatan Trenggalek, Kabupaten Trenggalek Propinsi Jawa Timur.

\section{METODE PENELITIAN}

Menggunakan metode penelitian deskriptif kuantitatif untuk mendiskripsikan keadaan objek yang terkait.Melakukansurvei, untuk mendapatkan informasi atau faktafakta dari gejala-gejala yang ada dan mencari keterangan secara faktual, baik tentang institusi ekonomi, kondisi sosial dari suatu daerah ataupun suatu kelompok. Informasi di dapat,dengan wawancara langsung (data primer) kepada produsen home industri 
tempe kripik, dengan menggunakan daftar pertanyaan atau kuesioner, dan data secara tidak langsung atau data sekunder.

Penentuan lokasi penelitian secara sengaja (purposive) dengan pertimbangan tertentu (Sugiyono,2016), yaitu di Lingkungan Kranding, Kelurahan Tamanan, Kecamatan Trenggalek, Kabupaten Trenggalek merupakan daerah sentra home industri tempe kripik. Untuk pengambilan sampel menggunakan metode simple random sampling, yaitu teknik untuk mendapatkan sampel yang langsung dilakukan pada unit sampling sebagai unsur populasi yang terpencil memperoleh peluang yang sama untuk menjadi sampel atau untuk mewakili populasi (Margono, 2004 : 126).Jumlah produsen home industri tempe kripik, yang tergabung dalam kelompok jajanan khas di Lingkungan Kranding, Kelurahan Tamanan, Kecamatan Trenggalek, Kabupaten Trenggalaek sebanyak 50 produsen, dan diambil 30 produsen sebagai sampel secara acak, dengan pertimbangan keterbatasan tenaga, waktu dan adanya asumsi bahwa seluruh populasi seragam atau homogen.Untuk pengumpulan data menggunakan observasi, wawancara dan dokumentasi.

Untuk analisis data, menggunakan analisis biaya (1) ; analisis penerimaan (2) ; analisis pendapatan atau keuntungan (3) ; dan analisis regresi linier berganda (4).

$\mathrm{TC}=\mathrm{TFC}+\mathrm{TVC}(1)$

$\mathrm{TR}=\mathrm{Q} \times \mathrm{P}(2) \pi=\mathrm{TR}-\mathrm{TC}(3)$

$Y=a+b 1 X 1+b 2 X 2+b 3 X 3+\ldots+b n X n$

Hipotesis pada penelitian ini adalah di duga (1) bahwa home industri tempe kripik memberikan keuntungan usaha, (2) bahwa faktor umur, tingkat pendidikan dan pengalaman atau lama usaha mempengaruhi pendapatan/ keuntungan produsen home industri tempe kripik, dan (3) bahwa faktor pengalaman atau lama usaha adalah faktor yang paling berpengaruh terhadap pendapatan/ keuntungan produsen home industri tempe kripik.

\section{HASIL DAN PEMBAHASAN}

\section{A.Letak Geografi Lokasi Penelitian}

Kelurahan Tamanan, Kecamatan Trenggalek, Kabupaten Trenggalek terletak pada 111.70467 BT - 8.05453 LS, dengan topografi wilayah berupa dataran, dan luas sebesar $3.031 \mathrm{Ha}$ atau $30.310 \mathrm{Km} 2$. Wilayahnya terbagi dalam 3 (Tiga) Lingkungan, 5 (Lima) RW dan 14 RT, yaitu Lingkungan Darang, Lingkungan Kranding dan Lingkungan Cengkong. 
Dengan Adapun batas-batas wilayah Kelurahan Tamanan, sebagai berikut :

Sebelah Utara : Kelurahan Ngantru

Sebelah Selatan : Kelurahan Kelutan dan Desa Salamrejo

Sebelah Timur : Kelurahan Ngantru dan Kelurahan Sumbergedong

Sebelah Barat $\quad$ : Desa Buluagung dan Desa Sumber

Untuk mengetahui distribusi penggunaan tanah dan luas tanahnya dapat dilihat pada tabel dibawah ini.

\begin{tabular}{|c|c|c|c|}
\hline No & Jenis Penggunaan Lahan & Luas (Ha) & Persentase (\%) \\
\hline \multirow[t]{5}{*}{1} & Lahan Sawah : & & \\
\hline & - Irigasi teknis & 402 & 13 \\
\hline & - Irigasi $1 / 2$ teknis & 266 & 9 \\
\hline & - Irigasi sederhana & 125 & 4 \\
\hline & - Tadah hujan & 284 & 9 \\
\hline \multirow[t]{6}{*}{2} & Lahan Kering & & \\
\hline & - Pekarangan & 1.022 & 34 \\
\hline & - Tegal/Kebun & 902 & 30 \\
\hline & - Hutan Rakyat & 26 & 1 \\
\hline & - Hutan Negara & 3 & 0 \\
\hline & Jumlah & 3.031 & 100 \\
\hline
\end{tabular}

Sumber Data : Kantor Kelurahan Tamanan, 2019

Bahwa $34 \%$ penggunaan tanah di Kelurahan Tamanan berupa tanah pekarangan, yaitu seluas 1.022 ha, atau $34 \%$ dari luas tanah yang ada pada Kelurahan Tamanan

\section{B.Keadaan Pertanian.}

Distribusi penggunaan lahan pertanian di Kelurahan Tamanan, Kecamatan Trenggalek, Kabupaten Trenggalek dapat dilihat pada tabel dibawah ini. 
Tabel 2Distribusi Penggunaan Lahan Pertanian, Produksi dan Produktivitas Tanaman Pangan di Kelurahan Tamanan, Kecamatan Trenggalek, Kabupaten Trenggalek

\begin{tabular}{lllll}
\hline No & Jenis Tanaman & Luas Panen(Ha) & Produksi Kw & Produktivitas Kw/Ha \\
\hline 1 & Padi Sawah & $2.918,3$ & 62,6 & 0,02 \\
2 & Padi Ladang & 40 & 42,4 & 1,06 \\
3 & Jagung & 549,7 & 64,7 & 0,12 \\
4 & Ubi Kayu & 1.500 & 245,6 & 0,16 \\
5 & Kacang Tanah & 4 & 14,4 & 3,6 \\
6 & Kedelai & 164,5 & 19,4 & 0,12 \\
\hline
\end{tabular}

Sumber Data : Kantor Kelurahan Tamanan, 2019

Dari tabel diatas, diketahui produktivitas kedelai di Kelurahan Tamanan termasuk kecil sekali, sedang produktivitas kedelai pada tingkat Kecamatan Trenggalekberdasarkan catatan BPS Kabupaten Trenggalek, sebesar 21,71 (Kw/Ha).

\section{Keadaan Penduduk}

Jumlah penduduk di Kelurahan Tamanan, Kecamatan Trenggalek, Kabupaten Trenggalek adalah sebesar 5068 jiwa.Untuk mengetahui keadaan atau komposisi penduduk berdasarkan jenis kelamin di Kelurahan Tamanan Kecamatan Trenggalek Kabupaten Trenggalek, dan penjelasan lainnya dapat dilihat pada sajian dibawah ini.

\begin{tabular}{|c|c|c|c|}
\hline No & Jenis Kelamin & Jumlah (jiwa) & Persentase (\%) \\
\hline 1 & Laki-Laki & 2463 & 49 \\
\hline 2 & Perempuan & 2605 & 51 \\
\hline & Jumlah & 5068 & 100 \\
\hline
\end{tabular}

Untuk mengetahui keadaan penduduk berdasarkan umur, dapat dilihat pada tabel di bawah ini.

\begin{tabular}{|c|c|c|c|}
\hline No & Umur (Tahun) & Jumlah (jiwa) & Persentase (\%) \\
\hline 1 & $0-15$ & 1124 & 22 \\
\hline 2 & $15-64$ & 3051 & 60 \\
\hline 3 & $>65$ & 893 & 18 \\
\hline & Jumlah & 5068 & 100 \\
\hline
\end{tabular}

Sumber Data : Kantor Kelurahan Tamanan, 2019 
Bahwa tabel di atas menunjukan $60 \%$ penduduk di Kelurahan Tamanan, Kecamatan Trenggalek, Kabupaten Trenggalek berada pada umur 15 - 64 tahun,yang menurut angkatan kerja, penduduknya termasuk usia produktif, yaitu sebesar 3.051 orang.

Keadaan penduduk berdasarkan pendidikannya di Kelurahan Tamanan, Kecamatan Trenggalek, Kabupaten Trenggalek dapat dilihat pada tabel di bawah ini.

Tabel 5 Keadaan Penduduk Berdasarkan Tingkat Pendidikan di Kelurahan Tamanan

\begin{tabular}{llll}
\hline No & Tingkat Pendidikan & Jumlah (Orang) & Persentase (\%) \\
\hline 1 & Tidak/ belum Sekolah & 681 & 13,44 \\
2 & Tidak Tamat SD & 592 & 11,68 \\
3 & Tamat SD/ Sederajat & 1.103 & 21,76 \\
4 & Tamat SLTP/Sederajat & 867 & 17,11 \\
5 & Tamat SLTA/Sederajat & 1310 & 25,85 \\
6 & Tamat S1 / Sederajat & 515 & 10,16 \\
\hline & J u m I a h & 5068 & 100
\end{tabular}

Sumber Data : Kantor Kelurahan Tamanan, 2019

Distribusi penduduk berdasarkan pekerjaannya di Kelurahan Tamanan, Kecamatan Trenggalek, Kabupaten Trenggalek dapat dilihat pada table dibawah ini.

Tabel 6 Keadaan Penduduk Berdasarkan Pekerjaannya di Kelurahan Tamanan

\begin{tabular}{|c|c|c|c|}
\hline No & Macam Pekerjaan & Jumlah (Orang) & Persentase (\%) \\
\hline 1 & Belum/ tidak bekerja & 698 & 13,77 \\
\hline 2 & Rumah tangga & 845 & 16,67 \\
\hline 3 & Pelajar/ Mahasiswa & 1197 & 23,62 \\
\hline 4 & Pensiunan & 120 & 2,37 \\
\hline 5 & PNS & 146 & 2,88 \\
\hline 6 & TNI & 102 & 2,01 \\
\hline 7 & POLRI & 100 & 1,97 \\
\hline 8 & Transportasi & 97 & 1,91 \\
\hline 9 & Karyawan Swasta & 299 & 5,9 \\
\hline 10 & Karyawan Honorer & 32 & 0,63 \\
\hline 11 & Buruh Harian lepas & 148 & 2,92 \\
\hline 12 & Buruh Tani & 110 & 2,17 \\
\hline 13 & Tukang Batu & 89 & 1,76 \\
\hline 14 & Guru & 103 & 2,03 \\
\hline 15 & Wiraswasta & 490 & 9,67 \\
\hline 16 & Petani/ pekebun & 147 & 2,9 \\
\hline 17 & Perdagangan & 196 & 3,87 \\
\hline 18 & Pekerjaan lainnya & 149 & 2,94 \\
\hline & $\mathrm{Jumlah}$ & 5068 & 100 \\
\hline
\end{tabular}

Sumber Data : Kantor Kelurahan Tamanan, 2019 


\section{Keadaan Ekonomi}

Yang dimaksud keadaan ekonomi dalam hal ini menyangkut adanya ketersediaan sarana dan prasarana ekonomi yang memadai di suatu daerah., karena akan dapat mendorong kegiatan perekonomian di daerah tersebut, serta dapat lebih tumbuh dan berkembang.

Berikut sarana prasarana ekonomi di Kelurahan Tamanan, Kecamatan Trenggalek, Kabupaten Trenggalek dapat dilihat pada table dibawah ini.

\begin{tabular}{cll}
\multicolumn{3}{c}{ Tabel 7 Sarana dan Prasarana di Kelurahan Tamanan } \\
\cline { 2 - 3 } No & Sarana \& Prasarana & Jumlah \\
\hline 1 & Mini Market & 1 \\
2 & Pasar Hewan & 1 \\
3 & Pasar Daerah & 1 \\
4 & Hotel & 1 \\
5 & Toko Kelontong & 186 \\
6 & Kedai Makanan & 16 \\
\hline
\end{tabular}

Dari tabel tersebut diatas menunjukkan bahwa sarana prasarana ekonomi di Kelurahan Tamanan, Kecamatan Trenggalek, Kabupaten Trenggalek berkembang cukup baik, dengan dibangunnya berbagai jenis sarana prasarana, ekonomi, antara lain, yaitu Mini Market ada 1 unit, Pasar Hewan 1 unit, Pasar Daerah 1 unit, Hotel 1 unit, dan Toko Kelontong sebanyak 186 unit serta Kedai Makan sebanyak 16 unit.

Dengan banyaknya jumlah toko kelontong ( 186 buah took ) yang ada di Kelurahan Tamanan, maka akan membantu atau berpengaruh pada pemasaran tempe kripik. Begitu juga keberadaan kedai makanan (16 buah kedai) dan Hotel walaupun masih sangat terbatas adanya (1 buah hotel), diharapkan juga dapat membantu mempermudah produsentempe kripik dalam memasarkan produknya di dalam kota. Sekaligus dapat mendukung dan mendorong berkembangnya usaha home industri tempe kripik di Kelurahan Tamanan, Kecamatan Trenggalek, Kabupaten Trenggalek.

\section{E.Analisis Biaya Produksi}

Biaya yang dikeluarkan dalam proses produksi tempe kripik dibagi dalam dua macam, (1) biaya tetap yang antara lain untuk pembelian alat-alat proses produksi (biaya pemyusutan) dan lai-lain; (2) biaya tidak tetap, untuk pembelan bahan baku, tenaga kerja dan lain-lain. Untuk lebih jelasnya dapat dilihat pada tabel dibawah ini. 
Tabel 8 Rata-Rata Total Biaya Home Industri Tempe Kripik di Kelurahan Tamanan

\begin{tabular}{cllc}
\hline No & U ra I a n & Jumlah (Rp) & Persentase (\%) \\
\hline 1 & Biaya Tetap & 217.000 & 24,16 \\
2 & Biaya Tidak Tetap & 681.350 & 75,84 \\
\hline \multicolumn{2}{c}{ Jumlah } & 898.350 & 100
\end{tabular}

Sumber Data Primer Diolah, 2020.

Dari data tersebut, dapat diketahui rata-rata total biaya home industri di Kelurahan Tamanan, Kecamatan Trenggalek, Kabupaten Trenggalek, sebesar Rp 898.350,- dalam satu kali produksi.

\section{F.Analisis Pendapatan}

Untuk mengetahui berapa pendapatan atau keuntungan dari produsen tempe kripik dalam satu kali proses produksi dapat dilihat pada table dibawah ini.

Tabel 9 Rata-Rata Pendapatan Produsen Home Industri Tempe Kripik di Kelurahan Tamanan
\begin{tabular}{clc}
\hline No & U r a I a n & Jumlah (Rp) \\
\hline 1 & Penerimaan & 1.594 .000 \\
2 & Total Biaya & 898.350 \\
\hline & Jumlah Pendapatan & 695.650 \\
\hline
\end{tabular}

Dari tabel tersebut diatas, maka diketahui pendapatan atau keuntungan produsen home industri di Kelurahan Tamanan, Kecamatan Trenggalek, Kabupaten Trenggalek, dalam satu kali proses produksi sebesar Rp 695.650,-. Perlu diketahui penerimaan produsen tempe kripik dalam satu kali produksi, adalah Rp 1.594.000,yang berasal dari (2000 packing $x$ Rp 797,-), dimana 1 packing berisi 10 biji tempe kripik.

\section{G. Faktor-Faktor Yang Mempengaruhi Pendapatan}

Faktor-Faktor yang mempengaruhi produsen dalam menjalankan usahanya dalam hal ini adalah umur (1), pendidikan (2), dan pengalaman atau lama usaha (3). Untuk mengetahui data produsen tempe kripik berdasarkan umur, tingkat pendidikan dan pengalaman atau lama usaha, dapat dilihat pada table dibawah ini. 
Tabel 10 Data Produsen Tempe Kripik Berdasarkan Umur di Kelurahan Tamanan

\begin{tabular}{lllc}
\hline No & U m u r & Jumlah (Rp) & Persentase (\%) \\
\hline 1 & $<40$ & 1 & 3 \\
2 & $40-55$ & 17 & 57 \\
3 & $>55$ & 12 & 40 \\
\hline \multicolumn{2}{r}{ Jumlah } & 898.350 & 100
\end{tabular}

Sumber : Data Primer Diolah,2020

Dari data tersebut dapat diketahui, maka dapat diketahui $57 \%$ umur produsen home industri kripik tempe di Kelurahan Tamanan berada pada umur 40 - 55 tahun.

Tabel 11 Data Produsen Tempe Kripik Berdasarkan Tingkat Pendidikan di Kelurahan Tamanan

\begin{tabular}{cllc}
\hline No & Pendidikan & Jumlah (Orang) & Persentase (\%) \\
\hline 1 & SD & 25 & 83,33 \\
2 & SMP/SLTP & 3 & 10 \\
3 & SMA/ SLTA & 2 & 6,67 \\
\hline & Jumlah & 30 & 100
\end{tabular}

Sumber : Data Primer Diolah,2020

Tabel tersebut diatas menunjukan, bahwa 83,33\% tingkat pendidikan dari produsen home industry kripik tempe adalah lulusan SMA (Sekolah Menengah Atas pertama.Tentang pengalaman atau lama usahanya dapat di lihat pada tabel di bawah ini.

Tabel 12 Data Produsen Tempe Kripik Berdasarkan Lama Usaha di Kelurahan Tamanan

\begin{tabular}{cllc}
\hline No & Pengalaman (Tahun) & Orang & Persentase (\%) \\
\hline 1 & $<10$ Tahun & 1 & 3,34 \\
2 & $10-20$ Tahun & 17 & 43,33 \\
3 & $>20$ Tahun & 12 & 53,33 \\
\hline & Jumlah & 898.350 & 100
\end{tabular}

Sumber : Data Primer Diolah,2020

Berdasarkan hasil analisis yang menggunakan aplikasi SPSS, diperoleh hasilnya sebagai berikut : 


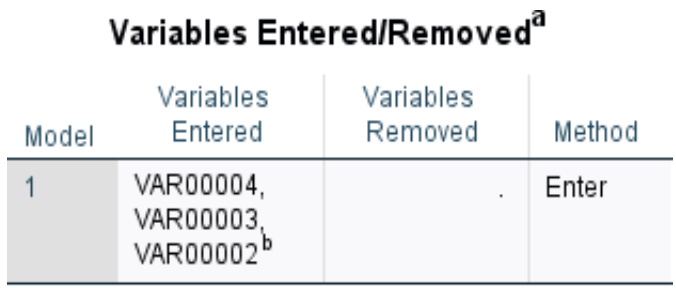

a. Dependent Variable: VAR00005

b. All requested variables entered.

Keterangan :

Variabel Umur (X1) = VAR00002

Variabel Pendidikan (X2) $\quad=$ VAR00003

Variabel Lama Usaha $(\mathrm{X} 3) \quad=$ VAR00004

Variabel Pendapatan $(\mathrm{Y}) \quad=$ VAR00005

Tabel "Output Entered/Removed" di atas memberikan informasi tentang variabel penelitian serta metode yang digunakan dalam analisis regresi.Adapun variabel independent yang dipakai dalam analisis ini adalah variabel Umur, Pendidikan dan Lama Melakukan Usaha atau Pengalaman.Sementara variabel dependent adalah variabel pendapatan usaha.Analisis Regresi menggunakan metode Enter, tidak ada variabel yang dibuang sehingga pada kolom "Variables Removed" tidak ada angkanya.

\begin{tabular}{ll|c|c|c}
\multicolumn{8}{c}{ Model Summary } \\
Model & $R$ & R Square & $\begin{array}{c}\text { Adjusted R } \\
\text { Square }\end{array}$ & $\begin{array}{c}\text { Std. Error of } \\
\text { the Estimate }\end{array}$ \\
\hline 1 &, $120^{\text {a }}$ &, 014 &,- 099 & 196449,8649 \\
\hline \multicolumn{3}{l}{ a. Predictors: (Constant), VAR00004, VAR00003, VAR00002 }
\end{tabular}

Tabel "Model Summary" memberikan informasi tentang nilai koefisiendeterminasi, yaitu kontribusi atau sumbangan pengaruh variabel bebas secara simultan (bersama-sama) terhadap variabel terikat (pendapatan).Berdasarkan tabel "Model Summary" di atas, dapat diketahui nilai koefisien determinasi atau R Square adalah sebesar 0,014 dan nilai korelasinya atau "R" sebesar 0,120.

Besarnya angka koefisien determinasi sebesar 0,014 atau sama dengan 1,4\% menunjukkan bahwa variabel bebas secara bersama-sama pengaruhnya kecil sekali $(1,40 \%)$ atau tidak berpengaruh terhadap pendapatan yang diperoleh produsen home industri tempe kripik. 


\begin{tabular}{|c|c|c|c|c|c|c|}
\hline \multicolumn{7}{|c|}{ ANOVA $^{a}$} \\
\hline \multicolumn{2}{|l|}{ Model } & $\begin{array}{l}\text { Sum of } \\
\text { Squares }\end{array}$ & df & Mean Square & $\mathrm{F}$ & Sig. \\
\hline \multirow[t]{3}{*}{1} & Regression & $1,457 \mathrm{E}+10$ & 3 & 4857827863 & .126 & $944^{b}$ \\
\hline & Residual & $1,003 E+12$ & 26 & $3,859 E+10$ & & \\
\hline & Total & $1,018 E+12$ & 29 & & & \\
\hline
\end{tabular}

Tabel "ANOVA" memberikan informasi tentang ada tidaknya pengaruh variabel bebas secara simultan (bersama-sama) terhadap variabel terikat.Berdasarkan output tabel "ANOVA" di atas dapat diketahui bahwa nilai $F$ hitung adalah sebesar 0,126. Karena nilai $F$ hitung $(0,126)<F$ tabel 2.98, maka dapat dapat disimpulkan bahwa variabel Umur, Pendidikan dan Lama Usaha secara simultan (bersama-sama) tidak berpengaruh terhadap Pendapatan ( $\mathrm{Y}$ ) atau berarti tidak signifikan.

Dengan demikian, maka persyaratan agar dapat memaknai nilai koefisien determinasi dalam analisa regresi liner berganda tidak terpenuhi.

\begin{tabular}{|c|c|c|c|c|c|c|}
\hline \multicolumn{7}{|c|}{ Coefficients $^{\mathrm{a}}$} \\
\hline & & \multicolumn{2}{|c|}{ Unstandardized Coefficients } & \multirow{2}{*}{$\begin{array}{l}\text { Standardized } \\
\text { Coefficients } \\
\text { Beta }\end{array}$} & \multirow[b]{2}{*}{$t$} & \multirow[b]{2}{*}{ Sig. } \\
\hline Model & & B & Std. Error & & & \\
\hline \multirow[t]{4}{*}{1} & (Constant) & 442007,688 & 324632,882 & & 1,362 & .185 \\
\hline & VAR00002 & 3663,719 & 6653,506 & .142 & .551 & ,587 \\
\hline & VAR00003 & $-2148,259$ & 21661,619 & -020 & -099 & ,922 \\
\hline & VAR00004 & $-1018,326$ & 5605,077 &,- 047 & -182 & .857 \\
\hline
\end{tabular}

Tabel "Coefficients" memberikan informasi tentang persamaan regresi dan ada tidaknyapengaruh variabel bebas secara sendiri-sendiri terhadap variabel terikat.Berdasarkan tabel output "Coefficients" di atas, dapat diketahui bahwa nilai signifikansi variabel bebas (Umur $=0,587$, Pendidikan $=0,922$ dan Lama Usaha $=$ 0,857 ) yang lebih besar dari 0,05 , maka dapat disimpulkan bahwa tidak ada pengaruh masing-masing variabel bebas tersebut terhadap variabel terikat.

Hal ini juga dapat ditunjukkan dengan melihat nilai t-hitung masing-masing variabel bebas (Umur $=0,551$, Pendidikan $=-0,099$ dan Lama Usaha $=-0,182$ ) yang lebih kecil dari Nilai t-tabel $1.70562(0,05 ; 26)$ yang memberikan arti bahwa masingmasing variabel bebas tidak berpengaruh terhadap variabel terikatnya (Pendapatan).

\section{KESIMPULAN DAN SARAN}

\section{KESIMPULAN}

Bahwa usaha home industri tempe kripik di Kelurahan Tamanan, Kecamatan Trenggalek, Kabupaten Trenggalek, memberikan pendapatan atau keuntungan sebesar Rp 695.650,- dalam satu kali produksi. 
Bahwa faktor umur, tingkat pendidikan dan lama usaha atau pengalaman tidak berpengaruh terhadap pendapatan pengusaha home industri tempe kripik yang di Kelurahan Tamanan, Kecamatan Trenggalek, Kabupaten Trenggalek, baik secara bersama-sama maupun secara parsial.

Bahwa dari ketiga faktor tersebut, yaitu umur, tingkat pendidikan dan lama usaha atau pengalaman, ternyata tidak ada faktor yang paling berpengaruh terhadap pendapatan produsen home industri tempe kripik di Kelurahan Tamanan, Kecamatan Trenggalek, Kabupaten Trenggalek.

\section{S A R A N:}

Dari hasil penelitian tersebut di atas memberikan peluang untuk dapat melakukan penelitian lanjutan dengan menambahkan faktor lainnya.

Untuk meningkatkan produktivitas usaha dan keuntungan usaha dapat melakukan inovasi, terutama pada segi rasa selain rasaoriginal, agar lebih bervariasi, misalnya ada rasa pedas, rasa keju dan lain sebainya, untuk memenuhi keinginan pasar juga sekaligus dapat meningkatkan pendapatan

Untuk lebih meningkatkan efisiensi usaha, disarankan mengajukan PIRT dan membentuk kelompok atau organisasi resmi/sah secara hukum agar mudah memperoleh fasilitas pemerintah maupun swasta, juga dalam usaha mendapatkan penambahan modal apabila diperlukan untuk pengembangan usahanya.

Memperbaiki dan meningkatkan sistem pemasaran, tidak hanya pemasaran offline, tapi berusaha merambah ke pemasaran on-line agar jangkauannya lebih luas,

Meningkatkan potensi SDM nya, melalui pelatihan-pelatihan, baik yang diadakan pemerintah, kamar dagang setempat (Kadin Kabupaten Trenggalek) maupun instansi atau pihak lainnya

\section{DAFTAR PUSTAKA}

\section{Buku}

Ahmad, Firdaus dan Wasilah Abdullah. 2009. Akuntansi Biaya. Edisi 2., Jakarta Salemba Empat.

Arsyad, L. 2010. Ekonomi PembangunanEdisi ke-5. Yogyakarta: UPP STIM YKPN.

Aulia Tasman dan M. Havidz Aima,, 2013 Ekonomi Manajerial dengan PendekatanMatematis, PT Raja Grafindo Persada, Jakarta, hlm. 176.

Bustami, Bastian dan Nurlela. 2010. Akuntansi Biaya. Edisi kedua. Jakarta: Mitra Wacana Media. 
Jasfar, Farida. 2012. 9 Kunci Keberhasilan Bisnis Jasa. Jakarta : Salemba Empat.

Kimbal, R.W. 2015. Modal Sosial Dan Ekonomi Industri Kecil Sebuah Studi Kualitatif.Penerbit : Depublish, Yogyakarta.

Mankiw N,Gregory, dkk. 2012, Pengantar Ekonomi Makro. Jakarta: Salemba Empat.

Muhidin, SA dan Abdurahman M, 2017 Analisis Korelasi, Regresi, dan Jalur Dalam Penelitian cetakan ke- 3 Pustaka Setia Bandung

Salim, E., 2013, Kiat Cerdas Wirausaha Aneka Olahan Kedelai, Penerbit Andi, Yogyakarta.

Sugiyono. 2011. Metode Penelitian Kuantitatif Kualitatif dan R\&D cetakan ke - 13 ALFABETA, cv Bandung:

Sugiyono, 2016. Metode Penelitian Administrasi. Alfabeta. Bandung.

Anggraeny, A.M.S, Husinsyah, dan Syarifah M.. 2011. Analisis Rentabilitas UsahaPembuatan Tempe di Kelurahan Sidodadi Kota Samarinda. Jurnal Ekonomi Pertanian dan Pembangunan. 8 (2) : 1- 4.

Arifin. N.K., Mustika, M. 2013. Analisis Pendapatan Pengerajin Perak di desa Kamasan Kabupaten Klungkung. E Jurnal Ekonomi Pembangunan. Vol. 2 No. 6. Hal 277-313.

Bagas, W S, Rifki K , 2018 Analisi Determinan Pendapatan Usaha Industri Mikro Kecil Tahu Di Trunan, Tidar Selatan, Magelang Selatan Kota Magelang, Jurnal Dinamika Ekonomi Pembangunan Vol 1 No 3 https://ejournal.undip.ac.id/index.php/dinamika_pembangunan/index

Dewi A P, Edy P, Bambang M S, 2016 - Analisis Efisiensi Ekonomi dan PendapatanPengrajnmTempe Di Kabupaten Klaten, Journal of Social We fareKesejhteraan Sosial-vol.1, No 02 trilogi.ac.id/journal/ks/index.php/jks/article/view/343

Elfrida, S M, Adeline N H, 2016 Analisis Pendapatan Usaha Industri Jamu di Kelompok Tani Prima Mandiri Desa Usapinonot, Jurnal Agribisnis Lahan Kering Vol 1 No 03 AGRIMOR DOI: https://doi.org/10.32938/ag.v1i03.265

Punde, M, La Ode G, Abdul G, Ilma S R , 2019 Analisis Nilai Tambah Usaha Home Industry Pengolahan Kopi Tolaki di Desa Tridana Mulya Kecamatan Landono Jurnal IImiah Agribisnis (JIA) Vol 4 No 5DOI: http://dx.doi.org/10.33772/jia.v4i5.7916

Rahayu W, Erlyna W R, 2010 Analisis Efisiensi Ekonomi Penggunaan FaktorFaktorProduksi Pada Usahatani Kedelai Di kabupaten Sukoharjo - Journal of Sustainable Agriculture - vol.25 No. 1 (2010) - Cakra Tani

Sholeh, Y, 2017 Peranan Home Industri Emping Melinjo Dalam Meningkatkan Pendapatan Keluarga Di Kecamatan Burneh Kabupaten Bangkalan, Journal AAI PERHEPI Vol.6, No 1 https://journal.trunojoyo.ac.id/agriekonomika/article/view/1905 , DOI: https://doi.org/10.21107/agriekonomika.v6i1.1905 
Supri Anggraini,D , Makmur M, Afrizal A, 2019 Analisis Faktor-Faktor Yang Mempengaruhi Pendapatan Industri Kecil Pengusaha Tahu Di Kecamatan Bonai Darussalam, Vol.1 No 2 HIRARKI Jurnal IImiah Manajemen Dan Bisnis DOI: https://doi.org/10.30606/hirarki.v1i2.187

Wibowo, D , Evy M, Eliza E 2020 Analisis Pedapatan Agroindustri Gula Kelapa Di Kecamatan Tempuling Kabupaten Indragiri Hilir Pekanbaru Jurnal Sosial EkonomiPertanian dan Agribisnis, Vol 16 No 2 https://jurnal.uns.ac.id/sepa/article/view/35336DOI: https://doi.org/10.20961/sepa.v16i2.35336

Widowati, S. Erliana, G. dan S.S. Antarlina.2009. Varietas Unggul Kedelai untukBahan Baku Industri Pangan. Jurnal Litbang Pertanian. 28 (3).Balai Penelitian Kacangkacangan dan Umbi-umbian. Malang.

Al-Kautsar, Hamid. 2013. Analisis Kelayakan Industri Rumah Tangga Tempe diKecamatan Gamping Kabupaten Sleman Yogyakarta, Skripsi Jurusan Agribisnis Fakultas Pertanian, Universitas MuhammadiyahYogyakarta.

Fransisdo, T.O. 2011. ryanti, D. 2011. Analisis Kinerja, Nilai Tambah dan Strategi Pengembangan Agroindustri Kecil Kelanting. Skripsi. Fakultas Pertanian Universitas Lampung. Bandar Lampung.

Iryanti, D. 2011. Analisis Kinerja, Nilai Tambah dan Strategi Pengembangan Agroindustri Kecil Kelanting. Skripsi. Fakultas Pertanian Universitas Lampung. Bandar Lampung.

Lain-Lain

Badan Pusat Statistik 2018Produktivitas Tanaman Pangan, Kabupaten Trenggalek

Ferlina, F. 2009. Tempe. http://www.adln.lib.unair.ac.id/go.php. Diakses pada tanggal 2 Januari 2010.

Undang-Undang Republik Indonesia no. 11 Pasal 1 Tahun 2009 tentang Kesejahteraan Masyarakat

\section{Buku}

Adisasmita R. 2013. Pembangunan Kawasan dan Tata Ruang. Graha Ilmu: Yogyakarta

Wyatt, J. C, danSpiegelhalter, D. 1991. Field Trials of Medical Decision-Aids: PotentialProblems and Solutions,Clayton, P. (ed.): Proc. 15th Symposium on ComputerApplications in Medical Care. Vol 1, Ed. 2, McGraw Hill Inc, New York.

\section{Jurnal/Prosiding/Disertasi/Tesis/Skripsi}

Prasetya, E.2006. Case Based Reasoning untuk mengidentifikasi kerusakan bangunan. Tesis, Program Pasca Sarjana Ilmu Komputer, Univ. Gadjah Mada, Yogyakarta. 
Sukra, I. N. dan Handay, L. N. C. 2015. Pengaruh Penggunaan Buku Ajar (Modul) Terhadap Hasil Bahasa Inggris untuk Pertanian. Jurnal Teknologi Pendidikan Vol. 18 (3) $96-103$

\section{Lain-Lain}

Adminami01. 2020. Mengetahui Pengertian dan Rumus B/C Ratio dan R/C Ratio. https://rumusrumus.com/rumus-b-c-ratio-dan-r-c-ratio/ diakses pada tanggal 11 Agustus 2020

Harmoni. 2020. Perbedaan Biaya Tetap dan Biaya Variabel Yang Harus Anda Tahu.https://www.harmony.co.id/blog /perbedaan-biaya-tetap-dan-biaya-variabelyang-harus-anda-tahu. Diakses pada 10 September 2020. 